\title{
Fuat Sezgin'ın GAS'ı Bağlamında Erken Dönem Tefsir Literatürü Hakkında Bir Değerlendirme (1- 5. Asır)
}

\section{Muhammed İkbal Koyuncu* (1)}

\section{Giriş}

Yaklaşık bir asırlık ömründe eşine az rastlanır biçimde çeşitli ilim dallarında hacimli eserler bırakmış olan Fuat Sezgin'in çalışmaları araştırmacılar için kaynak olmanın ötesinde yaşamıyla bütünleşmiş bir azmin semereleridir. Zira üzerinde mesâi harcadığı hemen her meseleyle ilgili derin bir bakış açısı sunmuş olan Sezgin, diğer bir tabirle dönemin imkân ve koşullarında çalıştı̆̆ her konunun hakkını vermiştir. Fuat Sezgin'in Arap-İslam Bilimleri Tarihi ${ }^{1}$ isimli eserinin "Kur' an Tefsiri” kısmının değerlendirilmesinin birçok açıdan önemi bulunmaktadır. Bunların başında Sezgin'in bilimler tarihine dair yaptığı çalışmaların ilk aşamasının tefsire ait olması gelmektedir. Nitekim Sezgin'in doktora çalışması Ebû Ubeyde Ma'mer b. Müsenna'ya ait (ö. 209/824) Mecâzu'l-Kur'an isimli tefsir eserinin tahkik çalı̧̧masıdır. ${ }^{2}$ Müellifin tefsir ilmine dair diğer çalışmaları ise Ebû Ubeyd Kasım b. Sellam el-Herevî'ye ait (ö. 224/838) en-Nâsih ve'l-Mensûh fi'l-Kur 'âni'l-Azîzi isimli eserin tıpk1 basımıla, Ebu Bekir Muhammed b. Tayyib b. Muhammed el-Basrî el-Bakıllânî’nin (ö. 403/1013) el-İntisâr li'l-Kur'ân isimli eserin tıpkı basım çalışmasıdır. ${ }^{4}$ Bunların yanında Sezgin, değerlendirmesini yapacağımız Arap-İslam Bilimleri Tarihi kitabının ikinci bahsini özel olarak “Kur' an Tefsiri” başlı̆̆ına ayırmıştır.

1 Eserin Türçe'ye çevrilirken kullanılan başlık olmasından dolayı bu ismi kullanıyoruz.

2 Ebû Ubeyde, et-Teymî el-Basrî Ma'mer b. Müsenna, Mecâzu'l-Kur'ân, thk. Fuat Sezgin. Beyrut: Müessesetü'r-risâle, 1981.

3 Ebû Ubeyd Kasım b. Sellâm el-Herevî, en-Nâsih ve'l-mensûh fi'l-Kur'an, thk. Fuat Sezgin. Frankfurt: Institut für Geschichte der Arabisch-Islamischen Wissenschaften, 1985. Eserin bilinen tek tam nüshas1 Topkapı Sarayı müzesi kütüphanesinde III. Ahmed nr. 143 numarada bulunmaktadır.

4 Bakıllânî, Ebû Bekr Muhammed b. Tayyib Muhammed Basrî, el-İntisar li’l-Kur'ân, thk. Fuat Sezgin. Frankfurt: Institut für Geschichte der Arabisch-Islamischen Wissenschaften, 1986.

5 Sezgin, Arap-İslam bilimleri tarihi, 1: 22-57.

\footnotetext{
* Sorumlu Yazar: Muhammed ikbal Koyuncu (Arş. Gör.), İstanbul Üniversitesi, illahiyat Fakültesi, Temel İslam Bilimleri, İstanbul, Türkiye. E-posta: m.ikbal_68@hotmail.com, ORCID: 0000-0001-8285-1025 
Bu çalışmada, Fuat Sezgin'in GAS olarak isimlendirilen Geschichte des Arabischen Schrifttums adlı eserin "Kur'an Tefsir"i literatürünü ortaya koyarken nasıl bir yöntem önerdiği, başka bir deyişle onun yaklaşımından nasıl bir yöntem çıkarılabileceği analiz edilecektir. Ayrıca ilgili kısımda zikredilen eser ve müelliflerin, tefsire dair tabakât kitapları içerisinde bulundukları konumun tahliliyle, Carl Brockelmann'ın (ö.1956) Geschichte der Arabichen Litteratur isimli eserinden ayrıldığı yerler tespit edilmeye çalışılacaktır. Daha sonra eserin literatür kısmının genel bir portresi ortaya çıkarılacak eserin tefsir tarihi yazımında bulunduğu konum ve esere bağlı olarak yeni bir literatür denemesinin imkânı sorgulanacaktır.

\section{Tabakât Kitapları'nın Genel Yöntemi}

Tabakât sözlükte "üst üste olan iki şeyin birbiriyle uyuşması, derece, mertebe ve konum bakımından örtüşmesi” anlamındaki 'tabak' (sınıf, zümre) manasına gelmektedir. İslam telif geleneğinde ise "sahabe, tabiîn, âlimler, edip, şair ve sanatkârlar, sûfiler, düşünürler ve ayırıcı niteliklere sahip olan kişilerden söz eden telif türünü” ifade etmektedir. ${ }^{6} \mathrm{Bu}$ çalışmaların bazen ele aldığg müelliflerin belirli ayırıcı özelliklere sahip olmasını gaye edindiği gözlemlenirken bazen de müellifin düşüncesine matuf olarak belirli zaman diliminde önemli görülen her çalışmanın kayıt altına alınmasını amaçlayan eserler olduğunu söylemek mümkündür. Daha açık bir ifadeyle tabakât türü eserler belli bir kalıp içerisine girmekten öte müellifine bağlı olarak farklı içeriklere ve konulara hâiz kitaplar olarak değerlendirilebilir.

Kur'ân'ın inzâlinden itibaren yukarıda ifade edilen farklı gayelerle birçok tabakât türü eser ortaya çıkmıştır. Bunların tefsir tarihine kaynaklıkları açısından birkaçı hakkında genel olarak malumât zikretmek yerinde olacaktır. İlk olarak değinilecek eser Suyûti'ye ait (ö. 911/1505) Tabakâtü'l-Müfessirîn isimli eserdir. Bu eserde Suyûtî toplamda yüz otuz altı müfessirden bahsetmektedir. Eser içerisinde müellifin takip ettiği metodu ise öncelikle müfessirin uzunca ismini, meşhur olduğu yönünü, hoca ve talebelerini, yaptığı seyahatleri, doğum ve vefat tarihlerini belirttikten sonra, eserlerini zikretmek olmuştur. Ancak eser isimlerini herhangi bir kategori altında değerlendirmeye tâbi tutmamıştır. ${ }^{7}$

Tefsir tarihi açısından önemli olarak görülen diğer bir eser Dâvûdî’nin (ö. 945/1539) Tabakâtü'l-Müfessirîn adlı eseridir. Bu eserde de müellif yedi yüz dört müfessirin biyografisine dair bilgilere yer vermektedir. Eserin telif metodu genel olarak Suyûtî'nin metoduyla aynı olmakla birlikte biyografiler incelenirken faydalanılan kaynak ve müelliflerin adlarına da işaret edilmiş olması Suyûtî’nin

6 İsmail Durmuş, “Tabakât” TDV İslam ansiklopedisi, 39, (2001): 288-290.

7 Suyûti, Abdurrahman b. Ebî Bekir, Tabakâtü'l-müfessirîn, thk. Ali Muhammed Ömer. Kahire: Mektebetü Vehbe, 1396. 
metodundan ayrılan yönlerdir. ${ }^{8}$ Son olarak Ömer Nasuhi Bilmen'in (ö. 1971) Büyük Tefsir Tarihi eserini zikredebiliriz. Bu çalışmada müellif isimlerini zikrettiğimiz eserlerden farklı olarak müfessirlerin biyografilerine dair kimi zaman kısa olmakla birlikte geniş bilgiler vermiştir. Genel olarak diğer eserlerden fark1 ise müfessirlerin mesleklerine dair tanımlamaların yapılması ve ilmi bakımdan müfessirlerin tabakalarına ayrılmış olmasıdır. ${ }^{9}$

\section{Gas'ın Kur'an Tefsiri Literatü}

Fuat Sezgin, kitabın Önsöz kısmında, eserini Carl Brockelmann'ın (ö. 1956) Geschichte Der Arabischen Litteratur (GAL) isimli eserine zeyl yazma sâikiyle kaleme aldığını belirtmiştir. ${ }^{10}$ Nitekim literatür kısmında da Brockelmann'ın eseriyle zikrettiği isimler arasında kırk bir yerde aynı kaynakları belirtirken sadece yirmi bir yerde farklı müfessir ve onlara ait eserlerini zikretmektedir. Sezgin'in eserini kaleme almasının bir diğer sebebinin ise oryantalistlerin Kur'an tefsirine dair fragmanların Hz. Peygamber'e ulaşmamış olduğu iddiasına cevap arama çabası olduğu görülmektedir. Daha açık ifade etmek gerekirse Sezgin'in, İslâmî ilimlere dair belli bir literatür ortaya koyma gayretinin gizli bir sorunun cevabı mahiyetinde olduğu yahut İslam kültür mirasının temellerini sağlam bir şekilde ortaya koyma gayesine dayandığını söylemek mümkündür. ${ }^{11}$

Fuat Sezgin, öncelikle tefsir rivayetleriyle ilgili zikredilen problemlerin başında; ilk kaynakların içerisinde birbiriyle çelişen rivayetlerin oryantalistler tarafindan eleştiri odağına alınması geldiğini belirtmektedir. Sezgin, problem olarak görülen bu rivayetlerin varlığından haberdâr olduğunu ifade etmekle birlikte bu rivayetlerin sonraki Kur'an araştırmacıları tarafından bilindiğini ısrarla vurgulamaktadır. Nitekim kendisine göre bu rivayetler her ne kadar zayıf yahut İsrâilî haber olarak addedilseler de hadis kaynakları içerisinde senet zincirleriyle birlikte hiçbir değişiklik ve tahrife uğramadan günümüze ulaşmışlardır. Ona göre tefsir rivayetlerinin sonraki dönemlerde ihdas edildiği yahut herhangi bir mesnedinin olmadığı gibi iddialarda bulunanlar senet güvenilirliğini göz ardı etmektedirler. Söz gelimi Ebû Âmir Kabîsa b. Ukbe’nin (ö. 215/830) tefsire dair rivayetlerini Buhârî'nin (ö. 256/870) Sahih'in de kırk altı yerde kullandığını belirterek hadisin tefsire kaynaklık ettiğine ve her iki ilmin birbirlerinden ayrılmaz bütün olarak değerlendirilmesi gerektiğine dikkat çekmektedir. ${ }^{12}$

8 Davûdî, Muhammed Ali b. Ahmed Şemsüddin, Tabakâtü'l-müfessirîn. Beyrut: Dâru'l-kütübü'lilmiyye, t.y.

9 Bilmen, Ömer nasuhi, Büyük tefsir tarihi tabakâtü’l-müfessirîn. İstanbul: Ravza yayınları, 2008.

10 Sezgin, Fuat, Arap-İslam bilimleri tarihi, 1: IX.

11 İlgili yerler için bk. Sezgin, Arap-İslam bilimleri tarihi, 1: 24-25.

12 Sezgin, Arap-İslam bilimleri tarihi, 1: 45. 
Sezgin'in bu meyanda ilk dönemlerde tefsirin yazıya geçirilmesine dair savunmasını yaptığı en önemli eser Ali b. Ebî Talha (ö. 143/760) kanalıyla İbn Abbas'a (ö. 68/687) nispet edilen Tenvîru'l-Mikbâs min Tefsîr-i ibn Abbas isimli çalışmadır. Kendisine göre bu tefsir hadis usûlü kriterlerine göre muttasıl bir senetle İbn Abbas'a ulaşmış, aynı şekilde bu rivayetlerin tamamına Taberî (ö. 310/923) tefsirinde yer vermiştir. Bunların yanında Kur'ân'a dair Ali b. Ebî Talha haricinde İbn Abbas'tan rivayet edilen haberlerin farklı kanallardan günümüze ulaşmış olmasının ana sebeplerinden birisi; bu rivayetlerin İbn Abbas'ın halka açık olarak yaptı̆̆ derslerden öğrencilerinin kaydetmeleri yahut şahsi olarak dersler ve görüşmeler neticesinde vücut bulmuş olmasıdır. İbn Abbas'a nispet edilen rivayetlerin çelişkili gibi görülmesi ise İbn Abbas'ın ve talebelerinin zamanla görüşlerinin gelişmesi ve yorumlanması olarak değerlendirilmelidir. ${ }^{13}$ Nitekim ilk döneme ait tefsir rivayetlerinde sahabînin Hz. Peygamber'den işittikleriyle birlikte kendi yorumlarının da bulunması bu iddiayı güçlü kılmaktadır. Söz gelimi öğrencisi Mücahid'in (ö. 103/721) tefsir yaparken serbest yorumlarda mütesâhil davranması neticesinde Mu'tezile gibi mezheplerin kendilerine mesnet olarak kullandıkları müteşâbih ifadelerin mecazî yorumunun ilk örneklerini görmek mümkün olmuştur. Sezgin burada ilk olarak İbn Abbas'ın yazıyla uğraşan sahabî olmadığını belirterek; tarihçi Musa b. Ukbe'nin, Kurayb b. Ebî Müslim’den (ö. 97/715) hocası İbn Abbas’tan geriye bir deve yükü yazılı malzeme kaldığını bildirmektedir. Nitekim İbn Abbas'ın oğlu Ali (ö. 118/736), zaman zaman Musa'ya mektup yazıp ondan şu veya bu sahifeyi göndermesini rica ediyor, daha sonra o sahifeleri istinsâh edip Musa'ya geri gönderiyordu. ${ }^{14}$ Bu bağlamda Sezgin'e göre ilk tefsir faaliyetlerini oluşturan tefsir rivayetlerinin herhangi bir tebdile uğramadığ konusunda hemfikir olunduğu takdirde erken dönem nesir ve dil çalışmaları için bu faaliyetler büyük bir kaynak olacaktır. ${ }^{15}$

Sezgin'in özellikle üzerinde en fazla durduğu husus ilk tefsir eserlerinin hadis usûlü metoduna göre herhangi bir inkıtâa uğramadan kaleme alınması ve her iki ilim dalının ayrılmaz bir bütün olarak değerlendirilmesi gerektiğidir. Sezgin'e göre sonraki dönem araştırmacılarının dikkat etmedikleri bir diğer konu, ellerinde bulunan küçük yahut hacimli tefsir eserlerinin hiçbir dayanaklarının olmadığ düşüncesidir. Oysa ki kendisi h. 5. asra kadar dikkatlerden kaçan bu eserleri toplamış ve detaylarıyla zikretmiştir. İlk dönemlerden itibaren başta Kur'an olmak üzere hadisler muhtelif sahabî ve tabiîn nesli tarafından yazıya geçirilmiştir.

13 Sezgin, Arap-İslam bilimleri tarihi, 1: 26.

14 Bkz. İbn Sa'd, et-Tabakât, 5: 224, 293; Sezgin, Arap-İslam bilimleri tarihi, 1: 26.

15 Sezgin, Arap-İslam bilimleri tarihi, 1: 22. 
$\mathrm{Bu}$ faaliyet gittikçe artarak devam etmiş, zaman içinde yazı da tayin edici nakil yollarından biri haline gelmiştir. ${ }^{16}$

Burada ifade edilmesi gereken bir diğer bahis ise sonraki dönem tefsirlerinde ilk dönemde kaleme alınmış eserleri kaynak göstererek yapılan iktibasların keyfî ve indî bir şekilde olmayıp belirli usûl ve yöntemlerle ilgili rivayetlerin tetkike tabi tutulduğunun göz ardı edilmiş olmasıdır. Söz gelimi Mücahid'in (ö. 104/722) rivayet ettiği "Mesâbe" kelimesini açıklarken Taberî (ö. 310/923) üç farklı isnat zinciri kullanmıştır. Bu isnatlardan birini Mücahid'in (ö. 103/701) Tefsir eserine dayandırmış, diğerini Ma'mer b. Müsennâ'nın (ö. 209/824) tefsirine sonuncusunu ise İbn Ebî Necîh' in (ö. 131/748) elimizde şu anda bulunmayan eserine dayandırarak farklı ravilerden günümüze ulaşan tüm isnatları zikretmiştir. ${ }^{17} \mathrm{Bu}$ da göstermektedir ki sonraki dönem eserleri de ilk dönem kaynakları gibi rivayetlerin günümüze ulaşması yönünden sahihtir. Netice itibariyle Taberî’nin farklı kanallardan gelen rivayetleri eserine derc etmiş olması Sezgin'e göre güvenilirlik ve sıhhatin ana sebeplerinden birisi olmuş, Taberî gibi bir âlimin eserinden faydalanılarak tesbit yapılabilme olanağı böylelikle mümkün olmuştur. ${ }^{18}$

\section{Literatür Değerlendirmesi}

Sezgin'in kisaca $G A S$ olarak isimlendirilen eseri öncelikle okuyucuya Tefsir Tarihi açısından bir literatür okuması yapma imkânı sunmaktadır. Buna göre mezhep yönünden Sezgin'in sunduğu tefsir literatürü şu şekildedir:

\section{GAS'ta Zikredilen Tefsirlerin Mezhep Dağılımları}

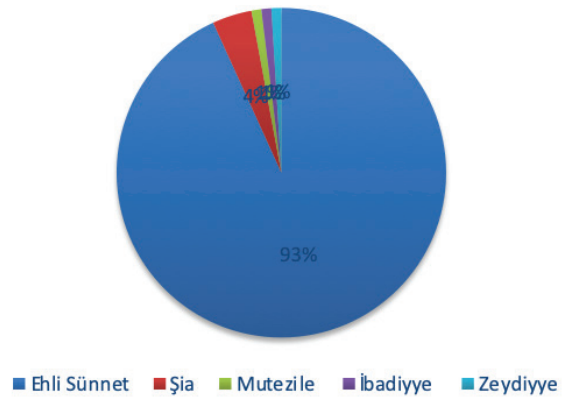

16 Nabia Abbott'un (ö. 1980) Studies in Arabic Literary Papyri I, Historical texts (Chicago 1957) ve Studies in Arabic literary papyri II: Qur'ānic commentary and tradition (Chicago 1967) adlı eserleri İslam öncesi ve sonrası yazının gelişimine dair kaleme alınmış ayrıca zikredilmesi gereken bir başka eserlerdir.

17 Taberî, Câmiu'l-beyân, 2: 26, 27, 28.

18 Sezgin, Arap-İslam bilimleri tarihi, 1: 23. 
Bu konuda Fuat Sezgin, tefsir tarihi içerisinde ele aldığ1 63 müfessirden \% 93'ünü Ehli Sünnet, \% 4'ünü Şia ve \% 1'er olarak İbâziyye, Zeydiyye ve Mutezile gibi mezheplere mensup alimlerin eserlerinden zikretmektedir. Ayrıca Sezgin her ne kadar altmış üç müellif üzerinde durmuş olsa da bu müfessirlere ait sadece tefsir eserlerini zikretmekle yetinmemiş kimi müfessirlerin tüm eserlerini ilgili kısımda belirtmiştir. Buna göre toplamda tefsir literatürü içerisinde bulunan eser sayıs1 yüz üçtür.

Sezgin'in zikrettiği müelliflerin vefat tarihleri esas alınarak bir dönem okuması da yapılabilmektedir. Buna göre Sezgin, h. 1. asra dair iki müellif, h. 2. asra ait yirmi beş, h. 3. asra ait on yedi, h. 4. asra ait yirmi, h. 5. asra ait ise dört müellif ismine eserinde yer vermektedir.

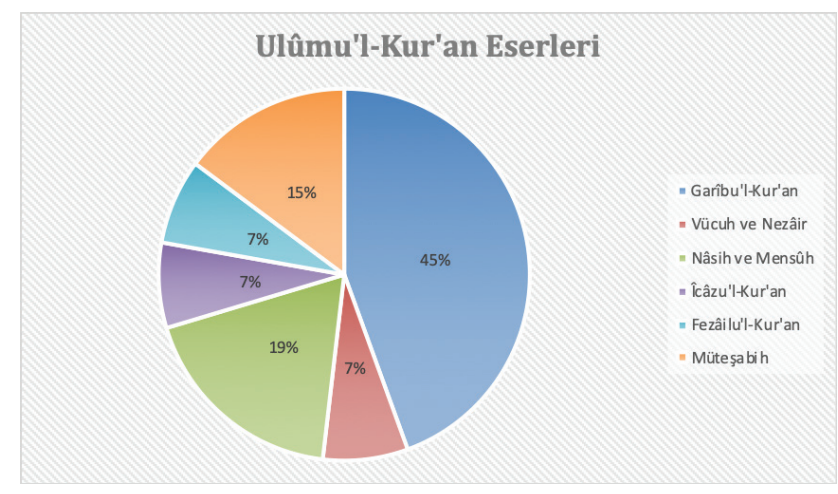

Burada Sezgin'in zikrettiği eserlerin sadece tefsir kitaplarından oluşmadığını, grafikte belirtildiği üzere büyük çoğunluğunun ulûmu'l-Kur'ân'a dair eserlerden oluştuğunu söyleyebiliriz. Bunlar içerisinde garîbu'l-Kur'ân'a dair on iki eser, vücuh ve nezâir'e dair iki, müteşâbihu'l-Kur'ân'la ilgili dört, nâsih ve mensûh'a da dair beş, îcâzu'l-Kur'an ve fezâilû'l-Kur'ân'la ilgili ikişer eser ismi zikredilmektedir. ${ }^{19}$

Görüldüğü üzere Fuat Sezgin tefsir tarihiyle ilgili kısımda müelliflerin sadece tefsire dair eserlerine yer vermekle yetinmemiş, gerekli bulduğu kısımlarda ayrıca müelliflerin tüm eserlerini zikrederek, kütüphane ve katalog numaralarını belirtmiştir. İbn Abbas gibi sahabîler hakkında mâlumat kısmını uzun tutarken kimi müfessirler hakkında ise yaşadığı dönemle ilgili ihtimalli olan bilgiler zikretmiştir. Bu bağlamda ifade edilecek olursa eser üzerinden müellifin kimliği gibi isme ve döneme dair bazı tespitler yapılabilirse de kesin olarak tefsir tarihi literatürü içerisinde bu bilgilerin yetersiz olduğunu ifade etmek gerekmektedir. Eser içerisinde eksik olarak tespit edilen bazı hususları ise detaylıca şu başlıklar altında değerlendirmek mümkündür;

19 Garîbu'l-Kur'ân'a dair zikrettiğimiz eserlerin içerisinde Meâni'l-Kur'an, Mecâzü'l-Kur'an ve Müşkilü'l-Kur'ân eserleri bir arada hesaplanmıştır. 


\section{Müellifin Tefsire Dair Çalışmalarının Haricinde Zikredilen Eserler}

Fuat Sezgin, zikrettiği bir müfessirin tefsirine dair eseriyle ilgili bilgiler vermekle yetinmemiş bunlara dair diğer eserlerinin gerek içeriğiyle gerekse kütüphane ve katalog durumlarıyla ilgili kayıtları sunmuştur. Söz gelimi İbn Abbas'ın tefsir eserlerine dair zikrettiği literatür haricinde ona ait Müsned, Medih Kasidesi, Havâs ba'd el-Ed'îya, Hadis el-Mîrac gibi eserlerle ilgili bilgiler serd etmiştir. ${ }^{20}$ Yine Katade b. Diâme'ye (ö. 117/735) ait tefsir eserlerinin yanında Kitâb el-Menasik eserine yer vermiş, ${ }^{21}$ Ebû Bistâm Mukatil b. Hayyân en-Nabâtî el-Belhi'ye (ö. 150/767) ait Kitabu'r-Red ale'l-Kaderiyye isimli kelam eseri, ${ }^{22}$ Ebû Hâlid Yezid b. Harun Zâdân el-Vastti'ye (ö. 206/821) ait Kitabu'l-Ferâid eseri tefsir literatürü içerisinde zikredilmiş eserlerdendir. ${ }^{23}$ Bunların yanında Ebû Muhammed Hasan b. Ali el-Hadi b. Muhammed el-Askeri'ye (ö. 260/874) ait Hirz ve Kelam fi'nNübüvve adlı eserleri, ${ }^{24}$ Ebû Abdullah Muhammed b. Eyyub b. Yahya b. ed-Durays er-Razi'ye (ö. 294/906) ait bir Hadis eseri, ${ }^{25}$ Ebû Abdullah Muhammed b. Abdullah b. İsa b. Ebî Zemenîn el-Merrî'ye (ö. 399/1088) ait Risale fí Akideti Ehli 's-Sünne, Muntehab el-Ahkam, Kudvet el-Ğazi ${ }^{26}$, Ebu'l-Kasim el-Hasan b. Muhammed b. el-Hasan b. Habib en-Nisaburi'ye (ö. 406/1015) ait Kitab el-Ukala el-Mecânîn adlı eser Sezgin' in tefsir literatürü içerisinde müfessirlere ait zikrettiği diğger eserlerdir. ${ }^{27}$

\section{Tam olarak Elde Bulunmamasına Rağmen Sezgin'in Müellife Nispet Ettiği Eserler}

Fuat Sezgin kimi eserlerin mevcudiyetinde ya da eserin müellife aidiyetinde ihtimalli ifadeler kullanmıştır. Söz gelimi İbn Abbas'a nispet ettiği Müsned, Medih Kasidesi, Havâss ba'd el-ed'îya, Hadis el-Mi'rac isimli eserler ihtimal üzere nispet edilmiş olup kendisi bu eserlerin müelliflerinin tam olarak tespit edilemediğini söylemektedir. ${ }^{28}$

Bununla birlikte Hasan-1 Basrî’ye (ö.110/728) ait Kitab el-Aded ile Nuzûl elKur'an adlı eserleri herhangi bir kütüphane ve katalog kaydı bulunmaksızın İbn

20 Sezgin, Arap-Íslam bilimleri tarihi, 1: 31.

21 Sezgin, Arap-Íslam bilimleri tarihi, 1: 35.

22 Sezgin, Arap-İslam bilimleri tarihi, 1: 40.

23 Sezgin, Arap-Islam bilimleri tarihi, 1: 45.

24 Sezgin, Arap-İslam bilimleri tarihi, 1: 46.

25 Sezgin, Arap-İslam bilimleri tarihi, 1: 46.

26 Sezgin, Arap-İslam bilimleri tarihi, 1: 52.

27 Sezgin, Arap-İslam bilimleri tarihi, 1: 53.

28 Sezgin, Arap-íslam bilimleri tarihi, 1: 31 . 
Nedim'in (ö. 385/995) Fihrist'i aracılığıyla kendisine nispet edilmiştir. ${ }^{29}$ Aynı şekilde Ebû Muaviya Huşeym b. Beşir b. Kasım es-Sülemî’ye (ö. 183/799) ait zikrettiği es-Sünen fi'l-Fıkh, el-Meğazi, el-Kırâât gibi eserlerde İbn Nedîm'e dayandırılmaktadır. ${ }^{30}$ Ayrıca Katâde b. Diame'ye (ö. 117/735) ait Avaşir el-Kur'an adlı eserin tespitinin tek dayanak noktası İbn Sâ'd'dır.(ö. 230/845) ${ }^{31}$ Mukatil b. Süleyman'a (ö. 150/767) ait Kitab el-Luğat fi'l-Kur'an, Kitab el-Cevâbât fi'lKur'an, Kitab er-Red ala 'l-Kaderiyye isimli eserler ile Ebû Halid Müslim b. Halid b. Muslim b. Said ez-Zencî el-Kuraş̂’ye (ö. 206/821) ait Kitab el-Feraid isimli eser sadece Hatib el-Bağdadî’nin (ö. 463/1071) rivayet etmesi için icazetli olduğuna dair bir kayıtla zikredilen diğer eserlerdir. ${ }^{32}$

\section{Taberî ve Sa'lebî’nin Tefsirlerinden İsnad Zincirleri Belirtilen Eserler}

Fuat Sezgin'in tefsir literatürünü ele aldığı bölümde belki de en dikkate alınması gereken noktalardan birisi müelliflere dair eser zikretmenin haricinde Taberî'nin (ö. 310/923) Câmiu'l-Beyan an Te'vîli Ây'il-Kur'ân isimli tefsir eseriyle Tarihu'l-Ümem ve'l-Mülûk isimli tarih eserinin içerisinden yahut Sa'lebi'nin (ö. 427/1035) el-Keşf ve'l-Beyân isimli eserinden tespit ettiği müelliflere dair rivayetlere dayanarak kaleme alınmış eser isnat etmektedir.Daha açık ifade etmek gerekirse Sezgin zikrettiği herhangi bir müellifin rivayet halkalarından birini Taberî ve Sa'lebi'nin eserlerinde gördügünde bunları net olarak değil de kabaca sayı zikrederek o müellifin tefsirdeki konumunu tasdik etmektedir. Söz gelimi Abdullah b. Abbas'a (ö. 68/687) ait Ali b. Ebî Talha el-Hâşimî'den (ö. 120/737) gelen rivayetlerin bir kısmını Haddesen̂̂ el-Musanna b. İbrahim el-Âmulî (ö. 240/854) Kâle Haddesena Abdullah b. Salih (ö. 223/837) Kâle Haddesena Muaviye b. Salih (ö. 158/774) ân Ali b. Ebî Talha ân İbn Abbas tarîkiyle, tefsirin diğer kısmını ise başka bir şeyhin Ali b. Davud et-Temîmî (ö. 262/875) rivayetiyle kullandığını belirtmektedir. ${ }^{33}$

Aynı şekilde Said b. Cübeyr' in (ö. 95/714) tefsirinin ortaya çıkmasında kütüphane katalog numarası haricinde dayanak noktası Taberî'nin tefsirinde ve Tarih'inde zikri geçen rivayet zinciri olmuştur. Bu gibi yerlerde Sezgin eser tespiti için tüm rivayetlerin incelenmesi gerektiğini ve sahih bir şekilde tefsir anlayışlarının ortaya çıkarılması gerektiğini ayrıca vurgulamaktadır. ${ }^{34}$

29 Sezgin, Arap-İslam bilimleri tarihi, 1: 34.

30 Sezgin, Arap-Íslam bilimleri tarihi, 1: 43.

31 Sezgin, Arap-İslam bilimleri tarihi, 1: 35.

32 Sezgin, Arap-İslam bilimleri tarihi, 1: 40, 45.

33 Sezgin, Arap-Islam bilimleri tarihi, 1: 30.

34 Sezgin, Arap-İslam bilimleri tarihi, 1: 32. 
Bazı yerlerde Sezgin sadece isnat zincirini zikretmekle yetinmemiş Taberî'nin tefsirinde geçen kaç tane rivayet bulunduğuna da yer vermiştir. Söz gelimi Mücahid b. Cebr'in (ö. 104/722) Haddesenâ Muhammed b. Amr el-Bahilî (ö. 249/863) Kale Haddesena Ebû Âsım en-Nebîl (ö. 212/827) Kale Haddesenî İsa b. Meymûn el-Mekkî Kale Haddesenâ ibn Ebî Necih an Mücahid isnadıyla yedi yüz yerde geçtiğini belirtmektedir. ${ }^{35}$

Bu örnekleri belirtmekle yetindiğimiz tefsir rivayetlerini hemen hemen her yerde vurgulayan Sezgin bunlardan başka; Şiî bir müfessir olan Ebu'l-Hasan Atıyye b. Sa'd b. Cunâde el-Avfî el-Kûfî'nin (ö. 111/729) Sa'lebi ve Taberî’de zikredilen bin beş yüz altmış rivayetten bahsetmektedir. Ayrıca Abdurrahman b. Zeyd b. Eslem el-Adevî el-Medenî'ye (ö. 182/798) ait tefsir rivayetinin Taberî' de yaklaşık bin sekiz yüz yerde kullandığını ifade etmektedir. Bazı yerlerde ise Sezgin, Taberî'de zikrettiği müfessire dair bir rivayet zinciri bulamadığı takdirde Taberî’nin râvî fihristine ihtiyaç olduğunu belirtmekle yetinmiştir. ${ }^{36}$ Bunların yanında tam olarak müellifini netleştiremediği kimi yerlerde ise öneri olarak bazı müfessirlere ait tefsir rivayetlerinin yeniden inşa edilebilirliğine işaret etmiştir. ${ }^{37}$

Emeviler dönemi içerisinde zikrettiği on altı müfessirden sadece ikisinde Taberî ve Sa'lebî'den herhangi birisinin eserlerinde geçen rivayetlere dair bilgi vermemiş̧tir. Buna mukabil Sezgin Abbasiler dönemine ait olarak zikrettiği otuz beş müfessirden dokuz müfessirin isnat zincirinin Taberî ve Sa'lebî'de bulunduğunu belirtmektedir.

\section{Fuat Sezgin Üzerinden Tefsir Tarihi Yazmanın İmkânı}

Fuat Sezgin dönemin imkân ve şartlarıyla Arap-İslam Bilimleri tarihine dair kültür temellerini ortaya koyan bir eser meydana getirmiştir. Eserde hem temel İslam bilimleriyle alakalı hemen hemen her ilimle ilgili geniş malumat zikredilmesi hem de ele alınan bütün konuların ana kaynaklara gidilerek tahkik edilmiş olması özellikle vurgulanması gereken noktalardır. Böyle bir eserin tefsir ilmi açısından ele alınması ise öncelikle hicrî 5. asrın ortalarına kadar mahtut literatürü önümüze sermesi açısından da değerlidir. Bununla birlikte yapılan çalışma dünyanın birçok kütüphanesinde yazma halde bulunan eserlere dair ferağ kayıtlarının belirtilmesi, yazmaların tek tek incelenerek Brockelmann'ın $G A L$ isimli eseriyle kütüphane katalog numaralarının mukayese edilmesi, ilk dönem müfessirlerin cerh ve tadille

35 Sezgin, Arap-İslam bilimleri tarihi, 1: 33.

36 Muhammed b. Ka’b b. Süleym el-Kurazi (ö. 118/736) bu şekilde zikredilen tabiîn büyügüdür. Sezgin, Arap-Isslam bilimleri tarihi, 1: 36, 37.

37 Sezgin, Arap-İslam bilimleri tarihi, 1: 37. 
müfessir kimliklerinin açığa çıkarılması ayrıca önemlidir. Tefsire dair fragmanlar şeklinde nakledilen eserlerin benzer ve karşıt yönlerinin belirtilmesi, aynı müellife dair eserlerin tahlillerinin yapılması, tefsir ilmi açısından çalışmanın önemini artırmaktadır.

Çalışmanın tefsir ilmine katkılarıyla birlikte, Sezgin'in konuya dair yaptığı araştırmaların bazı yönlerinin eleştiriye açık olduğu söylenebilir. Bu bağlamda ilk olarak tefsir ilmi ile ilgili kısmın, Brockelmann'ın eserine zeyl yazma düşüncesi haricinde hangi metod ve sâikle ele alındığ 1 meselesi gündeme getirilebilir. Zira sahabilere dair verilen malumat hayli eksik görünmektedir. Söz gelimi İbn Abbas'a dair zikredilen tefsir eseri Ali b. Ebî Talha kanalıyla zikredilen rivayet zincirinden oluşmaktadır. Ancak eserde erken dönem müfessir sahabi olarak zikredebilecek Hz. Ömer ya da Hz. Aişe gibi sahabilere dair herhangi bir tefsir rivayetinden söz edilmemiştir. ${ }^{38}$ Burada en iyi ihtimalle İbn Abbas'ın tefsirde Hz. Peygamber'in duasına mazhar olması ve küçük yaşlardan itibaren Hz. Peygamber'in yanında bulunması gerekçe olarak düşünülebilir. Ancak Hz. Ömer gibi bir sahabiden gelen rivayetlerden bahsedilmemiş olması Sezgin'in amacının en azından ashab kanalıyla gelen bütün tefsir rivayetlerinin değerlendirmeye tabi tutulması olmadığını göstermesi açısından yeterlidir. Bunun yanında eser içerisinde zikredilen ashaba dair tefsir fragmanlarının yapılacak sonraki çalışmalara kaynaklık etmesi, yeni bir tefsir literatürü çalışmasına diğer müfessir sahabileri eklemeye kapı aralaması açısından değerli olduğunu ifade etmek yerinde olacaktır.

Fuat Sezgin'in müfessirlerin eserlerini zikrettikten sonra hangi kütüphanede, hangi katalog numaralarında ve hangi mecmûâlar arasında bulunduğuyla ilgili kısa bilgiler vermesi, birçok yönden yeniden ele alınmayı gerektirmektir. Söz gelimi Sezgin Abdurrahman b. Zeyd b. Eslem el-Adevî el-Medenî’ye (ö. 182/798) ait rivayet zincirini Taberî’nin bin sekiz yüz yerde kullandığını ancak bu ravinin zayıf bir ravi olduğunu ifade etmektedir. ${ }^{39}$ Öyle anlaş1lyyor ki kendisi râvinin hal tercümesinde zayıf ibaresini kullanmakla birlikle rivayetlerin tamamının tahlilini yapmamıştır. Taberî üzerinde çalışacak bir araştırmacı sadece mezkûr ravinin isnadlarını gelişmiş modern dönem imkânları sayesinde kolay bir şekilde rivayetleri cem ederek bir değerlendirme imkânına sahip olabilir. Bu meyanda eserde ismi geçen tüm tefsir yahut tefsir rivayetleri dakik bir tetkike tabi tutularak çağdaş dönemde hemen hemen her araştırmacının dilinden düşürmediği sahabe asrında tefsirin ne olduğu, nasıl olduğuyla ilgili sahih bir tesbit imkânına erişebilir.

38 Fuat Sezgin üzerine Suudi Arabistan'da yapılan bir istidrâk çalışmasında bu konuya etraflıca değinilmiştir. Daha geniş bilgi için bk: Necm Abdurrahman Halef, İstidrâkât, 2.

39 Sezgin, Arap-İslam bilimleri tarihi, 1: 42. 
Yine Sezgin' in bir metot olarak Taberî'nin tefsirinde ele almadığı ancak Târîhu'lÜmem ve'l-Mülûk isimli eserinde zikrettiği bazı ravilere dair rivayet zincirleri ilk döneme dair kaleme alınmış siyer kaynakları taranarak ortaya çıkarılmalıdır. Bu eserler içerisinde bulunan tüm rivayetler ve rivayet kanalları belli bir metotla cem edilerek tefsirin siyere kaynaklık durumuyla ilgili daha sahih bilgilere ulaşılabilir. Böyle bir çalışma sonucunda israilî ve mevzû rivayetlerin tesbitine dair önemli bilgi edinilmiş olacaktır.

\section{Sonuç}

Tabakât türü eserler İslâm geleneğinde ilk asırlardan bu yana farklı gayelerle kaleme alınmış çalışmalar olarak tavsif edilmektedir. Bu tür eserlerden kimileri de müellifin amacına matuf olarak kütüphane kataloglarından yahut mahtut halde bulunan eserler cem edilerek ortaya çıkmıştır. Fuat Sezgin'e ait GAS olarak isimlendirilen Geschichte des Arabischen Schrifttums adlı eser de Carl Brockelmann'in Geschichte der Arabichen Litteratur isimli eserine zeyl yazma gayesiyle kütüphanelerde bulunan mahtut yahut matbu eserlere dair kaleme alınmış bir çalışmadır. Ancak Sezgin eserinin 'Kur'an Tefsiri' kısmında eseri kaleme alma amacindan birinin de İslam bilim tarihinin temellerini ortaya koyma amacı olduğunu göstermektedir. Bu bağlamda, "Kur'ân Tefsiri” kısmında müellifin uzunca ismini, cerh ve tadille ilgili durumunu vermiş ve eserin tefsir alanındaki yerine dair tespitlerde bulunmuştur.

Emeviler ve Abbasiler dönemini içine alan ve h. 430'a kadar kaleme alınmış tefsire dair eserlere yer veren eserde toplamda altmış üç müfessirin yüz dört eserinden bahsedilmiştir. Bu eserler sadece tefsire dair eserlerle sınırlı kalmamış kimi müfessirlerin kaleme aldığı tüm eserlerden söz edilmiştir. Bunların yanında her ne kadar başlık olarak "Kur'an Tefsiri”" belirlenmiş olsa da Kur'an ilimlerine dair toplamda yirmi sekiz eserden söz edilmiştir. Metot olarak bir müfessirin önce künyesi zikredilmiş daha sonra kısa olmakla birlikte cerh ve ta'dile dair hal tercümesi ve eserlerine dair kütüphane, katalog numaraları yahut ilgili müfessirin rivayet zincirleri zikredilmiştir.

Fuat Sezgin'in $G A S^{\prime}$ ’n tefsir ile ilgili bölümünün, dönemin imkân ve şartları göz önüne alındığında büyük bir emeğin mahsulü olmakla birlikte tamamlanmas1 gereken bazı yönlerinden bahsedilebilir. Bunlardan ilki -Kur'an Tefsiri kısmıyla ilgili olarak- böyle bir literatür ortaya koyarken tam olarak hangi yol ve metodun takip edildiğinin tespitine imkân vermemesidir. Diğer bir husus ise kendilerine eser nispet edilen bazı müelliflerin tam olarak o eseri kaleme aldıklarının tespitinin yapılamamasıdır. Bu çalışmanın özellikle h. 5/11. asra dair tefsir literatürüyle ilgili çalışmalara yol göstereceğini söylemek mümkündür. 


\section{Kaynakça/References}

Bakıllânî, Ebû Bekr Muhammed b. Tayyib. Muhammed Basrî. el-Intisar li'l-Kur'ân. thk. Fuat Sezgin. Frankfurt: Institut für geschichte der Arabisch-Islamischen wissenschaften, 1986.

Bilmen, Ömer Nasuhi. Büyük tefsir tarihi tabakâtü'l-müfessirîn. İstanbul: Ravza Yayınları, 2008.

Davûdî, Muhammed Ali b. Ahmed Şemsüddin. Tabakâtü'l-müfessirîn. Beyrut: Dâru'l-kütübü'lilmiyye, t.y.

Durmuş, İsmail. “Tabakât.” TDV İslam Ansiklopedisi 39, (2010): 288-290.

Ebû Ubeyde, et-Teymî el-Basrî Ma'mer b. Müsenna. Mecâzu'l-Kur'ân. thk. Fuat Sezgin. Beyrut: Müessesetü'l-risâle, 1981.

Ebû Ubeyd, Kasım b. Sellâm, el-Herevî. en-Nâsih ve'l-mensuh fi 'l-Kur'an, thk. Fuat Sezgin. Frankfurt: Institut für geschichte der Arabisch-Islamischen wissenschaften, 1985.

İbn Sad, Ebû Abdullah Muhammed b. Sa'd. et-Tabakâtü'l-kebir. Beyrut: Dâru'l-kütübü'l-ilmiyye, $1410 / 1990$.

Halef, Necm Abdurrahman. İstidrâkât alâ târîhi 't-türâsi'l-Arabî kısım et-Tefsîr ve ulûmü'l-Kur'ân. haz. Hikmet Beşir Yasin. Beyrut: Dâru ibnü’l-cevzî, 1422.

Sezgin, Fuat. Arap-İslâm bilimleri tarihi. İstanbul: Prof. Dr. Fuat Sezgin İslam bilim tarihi araştırmaları vakfi, 2015.

-------. Geschichte des Arabischen schrifttums. Leiden: Brill, 1967.

Suyuti, Abdurrahman b. Ebî Bekir. Tabakâtü'l-müfessirîn. thk. Ali Muhammed Ömer. Kahire: Mektebetü vehbe, 1396.

Taberî, Muhammed b. Cerir b. Yezid b. Kesir b. Galib el-Âmulî Ebû Cafer. Câmiu'l-beyân an te'vîli âyi'l-Kur'ân. thk. Dr. Abdullah b. Abdulmuhsin Türkî. Beyrut: Dâru Hicr, 1422/2001. 